\title{
Buddhism and the Sinhala Writing Tradition
}

\author{
J. W. R. W. K. Jayaweera
}

\begin{abstract}
The aim of this Paper is to study the influence of Buddhism on Sinhala language. Sinhala language has a continual history, which dates back to thousands of years. It seems to be a language with written evidences of great history, which dates at least to the $3^{\text {rd }}$ century B.C. Though several evidences could be presented to confirm that there was a writing practice using Sinhala language (Hela Basa) after the arrival of Prince Vijayain Sri Lanka that tradition developed systematically after the introduction of Buddhism as by Venerable Mahinda in $3^{\text {rd }}$ century B.C. He acquainted a Brähmī alphabet becomingly the Brāhmī scripts in Asoka inscriptions to expand the writing methodology in the island. In addition to that he translated Pali commentaries into Sinhala and that literary activity caused to spring a sophisticated Buddhist literature after -wards. The Brähmialphabet expanded in its evolution of Pali and Sanskrit scripts under the influence of Buddhism in the course of the time. Though Sinhala wordstock is an interesting combination of borrowed words from various languages, it should be mentioned that a considerable amount of Paliand Sanskrit words could be identified in the Sinhala tongue which have entered as homogeneous or derived words under the influence of Theravāda or Mahāyāna Buddhism. A special attention has been given to explore the Sinhala wordstock which has expanded with such kind of words, as a morphological study. There is a developed literary tradition in Sinhala language which possesses written evidence since the third century B.C. Sinhala language together with a Buddhist literary tradition evolved gradually and signs of Diglossia began to emerge in the course of time. While the spoken practice rapidly evolved by contacting with other languages as well as it developed as a living language, however writing on the other hand had barriers. As a result the difference between the writing and speech (colloquial practice) expanded. The Buddhist influence is visible explicitly not only in written Sinhala but also in colloquial Sinhala. The attempt of this article to study this language form nourished by Buddhism comprehensively.
\end{abstract}

Keywords:- Derivation, Borrowing Homogeneous words., Derived words, Folk Religion, Colloquial Sinhala.

The aim of this Paper is to study the influence of Buddhism on Sinhala language. Sinhala language has a continual history, which dates back to thousands of years. It seems to be a language with written evidences of great history, which dates at least to the $3^{\text {rd }}$ century B.C. Though several evidences could be presented to confirm that there was a writing practice using Sinhala language (Hela Basa) after the arrival of Prince Vijayain Sri Lanka that tradition developed systematically after the introduction of Buddhism as by Venerable Mahinda in $3^{\text {rd }}$ century B.C. He acquainted a Brāhmī alphabet becomingly the Brāhmī scripts in Asoka inscriptions to expand the writing methodology in the island. In addition to that he translated Pali commentaries into Sinhala and that literary activity caused to spring a sophisticated Buddhist literature after -wards. The Brāhmialphabet expanded in its evolution of Pali and Sanskrit scripts under the influence of Buddhism in the course of the time.

Though Sinhala wordstock is an interesting combination of borrowed words from various languages, it should be mentioned that a considerable amount of Paliand Sanskrit words could be identified in the Sinhala tongue which have entered as homogeneous or derived words under the influence of Theravāda or Mahāyāna Buddhism. A special attention has been 
given to explore the Sinhala wordstock which has expanded with such kind of words, as a morphological study.

There is a developed literary tradition in Sinhala language which possesses written evidence since the third century B.C. Sinhala language together with a Buddhist literary tradition evolved gradually and signs of Diglossia began to emerge in the course of time. While the spoken practice rapidly evolved by contacting with other languages as well as it developed as a living language, however writing on the other hand had barriers. As a result the difference between the writing and speech (colloquial practice) expanded. The Buddhist influence is visible explicitly not only in written Sinhala but also in colloquial Sinhala. The attempt of this article to study this language form nourished by Buddhism comprehensively.

Keywords :- Derivation, Borrowing Homogeneous words., Derived words, Folk Religion, Colloquial Sinhala.

\section{INTRODUCTION}

The third Buddhistcouncil headed by Ven. Moggaliputta Tissa was one of the most important events in the history of Buddhism. Its most significant out come was to bring Theravāda Buddhism to Sri Lanka. This council was convened around 250 BCE by king Asoka, the greatest ruler of India. The third Buddhist council had a vital objective. This was to spread Buddhism beyond India by sending missionary monks to nine different countries. However the most important mission came to the island of Sri Lanka. This mission was led by none other than King Asoka's own son, Venerable Mahinda, who was to convert the king of Sri Lanka and all of his followers and subjects too. Ven.Mahinda before his passing away introduced not only the Buddha's teaching but also writing , new forms of art, architecture and literature to Sri Lanka society.

Ven. Mahinda performed a vital task to introduce a new writing tradition to Sri Lanka. Specially he introduced a Brahmin alphabet to expand the writing methodology. So many evidences can be found out to prove that there was a writing tradition using Sinhala language after arrival of prince Vijaya in Sri Lanka. But it was development systematically after venerable Mahinda's arrival in Sri Lanka. He translated Pali commentaries in to Sinhala Commentaries. Ven. Mahinda with mission utilized SinhalaLanguage to Preach dhamma.

Some devotees who embraced Buddhism restored some caves and they were offered to Buddhist monks. These offerings were written on inscriptions in Sinhala language. This language and shape of letters had very close resemblances with the language in inscriptions of Ashoka. Accordingly Buddhism influenced to the Sinhalese Language from $3^{\text {rd }}$ B.C.E. to present time not only for writing but also speaking. Sinhalese Language has borrowed so many Buddhist words to his word stock (Vocabulary). The Buddhist influence on Sinhala language can be seen in Orthography (letters) Etymology(words) and syntax (Sentences)

\section{APPROACH OF VENERABLE MAHINDA AND SINHALA WRITING TRADITION}

Buddhism was introduced to Sri Lanka by Mahinda and Sanghamittā, both of whom are believed to be children of Asoka. Not only were the people of Sri Lanka brought under the influence of a new religion, but the mission paved the way for the magnificent achievements of Mauryan civilization to reach the shores of this lsland. How ever as a result of the new religion and civilization Sri Lanka became the spiritual center of Theravāda Buddhism.

A significant out come of the aeeival of ven. Mahinda was to introduce a new writing tradition and a literary tradition. How ever it should be mentioned that so many evidences can be 
found out to prove that there was a writing tradition using Sinhala language after arrival of prince Vijaya in Sri Lanka.

According to pali chronicles such as the Mahāvamsa (great chronicle) the Dipavamsa (History of the island) and Pali commentaries such as Samantapāsādikā, Vinayatțakathā there had been not only a spoken practice but also a writing practice after the arrival of prince Vijaya. Accroding to those sources, following incidents can be submitted briefly to prove that matter.

Vijaya arrived at Tambapanni from north India after he was banished by his father because of his unruly behaviour. Together with seven hundred of his colleauges, he come in search of a new home. The area where they fended was the abode of Yakkha (the inhabitants of Yakkas) and there was a Yakka city called Sirisavattu.. There Vijaya met a Yakkinni (Female Yakka) by the name of Kuweni (Kuwannā). Prince Vijaya achieves the leadership assassinating inland Yakka (This is their tribe) leaders with the assistance of Kuweni (Kuwannā) ${ }^{1}$

Vijaya becomes a powerful monarch but could not be consecrated without a royal queen. The necessity of a Kattiya princess arose. As a result Vijaya sends a letter with a deligation to Madurāpura in India. Pandi the king of Madurā sends his daughter to island with a reply letter $^{2}$ The symbols used in these letters are not found. How ever they have utilized a language. It is cristal clear what Vijaya spoke was understood by Kuweni and what kuweni spoke was understood by Vijaya. Thus these languages in two countries should be similar each other.

After the crowning ceremony king Vijaya who got married a princess from Pandyan Kindom of India gave up Kuweni and two children. They went back to their relatives (Yakkhās) where the Yakkhās killed kuweni and two children fled to Malaya area (The central hills of Sri Lanka in the past). Other maidens of high brith also arrived and married the kings other followers. These followers of the king founded other settlements. king Vijaya ruled the island for38 years. As Vijaya had no children from his second marriage, in last years he sent prince sumitta a letter again to send a suitable person to the island to accept the kinship after Vijaya's ruling. As Simitta was too old then his son Panduvāsadeva decided to accept Vijaya's offer of the throne of Lanka. Panduvāsadeva arrived in Sri Lanka with 32 sons of Sumitta, andSumitta's ministers. ${ }^{3}$ According to Mahāwamsa king Panḍuvāsadeva had ten sons and one daughter. The elderst son was Abhaya and the daughter was Cittā. As her sight caused mental disturbances in men, She was called Ummāda cittā. It was predicted that Cittā would have a son who would kill the uncles of him ( Panduvāsu deva's Sons). As a result She was imprisoned in a turret and guarded by one hundred men. However this all strategies were unsuccessful and Cittā conseived a child. She named the Son as Pandukābhaya ${ }^{4}$

When Pandukābhaya was young, he was taught by a Brahman named panḍula. Pre - Buddhist Sri Lankan lay society was divided into four Parts. ${ }^{5}$ They are,

1; Brahmins (Chaplains)

2. Kshastriya ( Kings)

3 ¡Vaiśaya ( Trader , Farmers .....)

4. Sudra (Lowcast people) 
Brahmins were the educated clergy menof the time and were teachers of kings and princes. The had the knowledge of Four Vedās called Rig, Yajur , Sāma and Athrvan. panḍulaat Panḍulagama also was perfect of four vedās. The name "Vedapāragu" has been attributed him. ${ }^{6}$ pandulaBrahmin taught the prince Pandukābhaya and his own son the skills worthy of a king. Prince learnt well and achieved the literary ability. ${ }^{7}$ As well as king Abhaya has sent Pandukābhaya a secret letter ${ }^{8}$. So it is clear that both of them were literate.

According to above mentioned facts, we can prove undoubtedly that there was a writing method in pre Buddhist era. How ever this writing tradition was developed systematically after the arrival of Ven. Mahinda. He introduced a Brāhmi alphabet to expand the art of writing in Sri Lanka.After the introduction of Buddhim to Sri Lanka, Some devotees who embraced Buddhism restoredsome caves and those caves were offered to Buddhist monks. These meritorious activities were written on inscriptions. There, the above mentioned Brāhmi alphabet was utilized. Following Brāhmi inscriptions belong to 3 - 2 B.C.E.

1. Jhotiś(e)na - teraśa ativaśika Bata Śumanadatateraśa len(e ) Śagaśa9 ( The cave of the elder, Lord Sumanadatta, Disciple of the elder Jotisena, (is given) to the Saǹgha)

2. De (Va)napiya - mabarajhaha bariyaya bak(iniya) upaśika - Varupa(data)ya (le) ne $\mathrm{e}^{10}$ The cave of the female lay - devotee Varunadattā, sister of the wife of the great king Devanapiya.

3. 1) Badakarika - Prumaka Tiśs - puta Parumak Aśada. ${ }^{11}$

2) Gutaha lene

The cave of the chief Āsāthagutta, son of the chief Tissa, the Treasurer

4. Mahajhaha Gamani - Tiśaśa bariya upaśika - Kitakaya leṇe śagaśa ${ }^{12}$

The cave of the female lay -devotee Kitaka, wife of the great king Gāmaṇi Tissa, (is given) to the Sangha.

5. Gapati - Vega - jhitaya upaśika - Viśa ( kaya lene) ${ }^{13}$

The cave of the female ley - devotee Visākhā, daughter of the house - holder Vega.

The language and the shape of the letters have very close resemblances with the language in inscriptions of Asoka such as Sindhapur. Bhramagiri, Runmindei. After the arrival of ven. Mahinda and his delegation used Sinhala Language to preach Damma. As a result it caused to develop the language perfectly. This language was introduced as Prākrit Sinhala.

In this era Pali language influenced to Sinhala Language mostly,not only for writing practice but also for literary tradition. Reason for this situation was the influence of the Buddhism. Prākit Sinhala andPali language were very similar in pronunciation and the word order in the 
sentence. When we translate few Brāhmi inscriptions in to Pali, this resemblance can be identified clearly.

- Devanapiya Maharajhaha bariyaya bakiniya upaśika varunadataya lene $e^{14}$

Devāímpiya Mahārajassa bhariyāya bhaginiyā Upāsikā varunadattāya Lenan.

- (Gamani) uti Devanapiya maharajhaha jhaya śumana - deviya lene agata anagata catudiśa sagaśa ${ }^{15}$

Gamani Uttiyassa Dēvānam piya mahārājassa jāya śumanādeviyā Leṇan āgatanāyātassa Cātudisassa saǹgassa,

- Taladara Nagayaputa Devaha lene agata anagata catudiśa śagaśa16

- Tulādhara Nāgassa puttassa Devassa lenan Āgatānāgata cātuddisassa saǹghassa.

- Badakarika parumaka senaha bariya Sumanaya lene śagaśa ${ }^{17}$

Bhāndāgarika parumaka senassa bhariya sumanaya lene sagasa.

The influence of Pali language can be identified in orthography. Etymology as well as in syntax. Many scholars have proved that Sinhala is an Indu Aryan Language, rejecting Dravadian opinions. Above mentioned resemblances, between Pali and Sinhala can be utilized as an evidence to prove that Sinhala Language is an Indu Aryan language.

How ever as there were some limitations in early Sinhala language when Buddhist terms come through Pali $\mathrm{i}$, the pronunciation has been changed.

"Buddan் (o) Saranañ (o) Gacchāmi"

In this Pali sentence for the end of first two words zero ( o, Niggahitaya) has been used. But as there was not Zero (o) in the prakit Sinhala the pronunciation of above mentioned stanza has changed as,

“Buddam (m) Saranam (m) Gacchāmi

The Brāhmin alphabet in which limited letters were included, developed gradually by the passage of the time. According to the advice in Siyabaslakara which was written as an adaptation of Kāvyādarshaya of Daṇịin, the early Sinhala literature didn't exceed the Buddhist concepts.

\section{"Peden Budusiritạ"}

Although this instruction was given for the poety, it influenced to the Sinhala prose as well . When we have a search in to Sinhala literary tradition, this matter can be identified easily. This Buddhsit influence can be seen in Sinhala grammatical tradition also.

Sidat Sangarā is the oldest and reliable grammar of the Sinhala language extant. This book has been written in $13^{\text {th }}$ century B.C. i.e. In Dambadeniya era. The author has not forgotten to commence his task according to traditional way.

"Mahada Gandakili kara

Saunē Gewā dathata 


\section{Duhunan Denum Sandahā}

Karanem sidat sangarä $\bar{a}^{\prime 18}$

I offer my heart as a room full of fragrance for the Buddha who understood and concluded everything which is to know and Sidat Sangarā is done for the knowledge of bigginers.

The author hasn't forgotten to give prority to respect the Buddha before the commencement of analysis of contemporary Sinhalese grammar which was used for the poetry.

\section{BUDDHIST INFLUENCE FOR THE EXPANSION OF SINHALA WORDSTOCK}

After establishment of Buddhim in the island ven. Mahinda took various strategies to spread Dhamma with the help of King Devānampiyatissa .One was to introduce a new alphabet to expand the writing tradition and the other was to translate Pali commentaries in to Sinhala language. This step caused to develop Sinhala language with its wordstock. Buddhim was established in Sinhala as Helațuwā. This "Atuwa" influenced for the post Sinhalaliterature. A.W. Adhikarom mentions a list of "Helațuwā" in his book named Early History of Buddhism in Ceylon. The are,

- Mahațthakathā

- Mahāpaccariyațțhakathā

- Uttaravihārațthhakathā

- Kurundi Atțhakathā

- Andhakațțhakathā

- Sankhepațtahakathā

- Samyuttatțhakathā

- Anguttarațthakathā

- Abhidhammatțhakathā

- Sîhalațthakathā

- AtțhakathāCariyā

- Ácariyā

- Ācariya wāda

- Ācariya mata

- Therasallāpa

- Parasamuddavāsithera

- Vitaṇuavāda

- Porānā

- Poranakatherā

- Porānacāriyā

- Bhānakā 19

The commentator ven. Buddhagōsha came to the island is 5 century B.C. He translated these Ațuwā in to Pali language toexpand the knowledge of Buddhismof all Buddhists in the world. He used this "Helațuwā" to write down commentaries such as the Samntapāsādikā. However as a result of this translation, Heḷațuwā disappeared from the island. But it caused to expand the Sinhala language.

Some parts which were extracted from those Atuwā can be identified in the Dampiyā Ațuwā Gațapadaya, the Jāthaka Ațuwa Gatapadaya,the Visuddhi mārgayathe 
Abhidarmārthasangrahaya. Influence of these Ațuā, can be seen in Sinhala word stock, derivation, sentences patterns, and literary practice. When we analyse the literature in Anuradhapura Polonnaruwa and Dambadeniya that matter can be understood clearly.

When we pay our attention to the history of Buddhism taking Tripitaka (thee basket)s in to books in the day of King Vatțagāmini at Aluwiharaya (The temple of light) in Matale can be identified as a significant incident. This vital task caused to stabilize the Buddhaism and for the creation of a new literature. All those literary texts based on Buddhist perspectives. They were nourished byPali language. theAmāwatura, the Butsarana, the Saddhammaratnawaliya,the Saddammalankāraya, the Darma Pradīpikāwa are good examples for this matter.

When we use a word borrowed from another language without changingits form, it is calleda homogeneous words. These words are utilized in mixed Sinhala language. Sinhala word stock has expanded fromsuch kinds of words achieved from Buddhism. Here usually "j" (wa) or " $h$ " (ya) are added to the end of the words. These letters are called suffixes.(m\%;H)

Pūjāwa ( offering)

Wandanāwa ( worship)

Ārādhanāwa (invitation)

Sālāwa (hall)

Sīmāwa (limit)

Kathinaya (Katina)

Dānaya (Alms)

Tūpaya (Pagoda)

Bōdhiya (Bodhi)

Vankagiriya

Mūsilaya

Following words also can be utilized as homogeneous mixed Sinhala words related to Buddhism.

Kusalaya ( merit)

Samādhiya ( concentration)

Śarīraya ( Body)

Jātiya ( birth)

Jarāwa ( old age)

Viyādhiya ( decay)

Maraṇaya ( death)

Śokaya (grief)

Gītikāwa ( Verse)

Taṇhāwa (desire)

Paticaca Samuppādaya ( theory of Cause and effect)

Other Pali words have entered to Sinhala language as derived words. When a word is used changing its form to another language that word is called a derived word. Such kinds of words can be identified in Sinhala language commonly.

- cankamana $\rightarrow$ Sakmana - Walking

- Majjhima patipadā $\rightarrow$ Mạdum Piliweta- middle Path

- Vassāvāsika $\rightarrow$ Wạsisalu - robe

- gilānapaccaya $\rightarrow$ Gilanpasa- medicine.

- Besajja $\rightarrow$ Behet - Medicine

- Vandanā $\rightarrow$ Vedeema -Worship

- Pațimāghara $\rightarrow$ Pilimage -Shrine room 
- Taṇhā $\rightarrow$ Thaña - desire

- Dharma $\rightarrow$ Dahama- Canon

- Paripāti $\rightarrow$ Piliwela - order

- Ânisansa $\rightarrow$ Anuhas - efficacy

- Paritta $\rightarrow$ Pirit- Pirith

- kleșa $\rightarrow$ Keles - defilements

- Vibhanga $\rightarrow$ Bedīma - division

- Nibbana $\rightarrow$ Nivana - Nibbana

- Rājā $\rightarrow$ Raja - King

- Chakkavatti $\rightarrow$ Sakviti - universal

- Mātā $\rightarrow$ Mava - Mother

- Loka $\rightarrow$ Lova - World

- Soka $\rightarrow$ Sowa - grief

- Pitā $\rightarrow$ Piyā - Father

- Dhītā $\rightarrow$ Duwa-Daughter .... ect

Large amount of worlds have been used to introduce the lord Buddha. When we have a look in to Sinhala prose and poetry, many words can be identified. There is no a limit of words for Buddha.

Diyanā

Dinisuru

Dinaisuru

Narasī

Narapawara

Naradamseri

Pasạs

Pạans

Bagawat

Budu

Anadiwara

Isuru

Thilonā

Thilōguru

Dasabala

Dasabul

Damraja

Dinidu

Dininda

Diyabap

Diyes

Mahaisi

Mararupu

Muni

Munidu

Mokeduru

Lowaga

Lovidu

Vinā

Vināyaka

Satara

Savana

Savani

Saman Baduru

Sirigana

Sirimat

Sugat

Sugatidu ${ }^{20}$

After establishment of Buddhism in Sri Lanka many people gathered around this new religion. They gave up there mythical beliefs. People didn't forget to get the blessing of triple gems,for there all special activities in the life. All male andfemale devotees giving up their selfhood, hatred, delusion developed the loving kindness, happiness and equanimity The village was organized according to four concepts of tank stupa, village and temple. All villagers gathered to the temple or monastery to listen dhamma sermons in the evening. Bhikkhus not only preached damma but also taught children, held discussions. held various meritorious activities. As a result many Buddhist words included inPali language. Transferred 
to Sinhala language specially from damma sermon. Such wordsadded to colloquial Sinhala can be given with few titles.

Proper nouns.

- Saddhātissa

- Saǹghatissa

- Saǹghadāsa

- Saǹghabodhi

- Buddhadatta

- Dammasēna

- Dammakitti

- Dammarāja

- Mahinda

- Ānanda

- Māyā

- Gōtami

- Vishāka

- Anula

- Sāmā

Buddhist Retuals

- Bodhipūjā

- Pirith

- sajjāyana

- Kathina

- Giribhanda

- Yugāsana

- Perahạra

Pair of words

- Bana Daham (Damma Sermons)

- Melowa Paralowa (This world and next world)

- Sirit Virit (Formalities)

- Paul Pansal (Family and temple)

- Vehera Vihara (Shrines)

- Ancca Dukkha (Impermanence and suffering)

- Vandana Mana (Worship)

Buddhist Environment

- Bodhiya (Bodhi tree)

- Viharaya ( Shrine room)

- Maluwa ( yard)

- Pilimaya ( statue)

- Dange ( House of Alms)

- Aramaya (Monastery)

- Pansala ( Temple)

A special usage if words are used for activities of Bhikkus is in the temple or the monastery. These words have formed according to devotee's respect for the clergy.

Vaḍi (comes) 


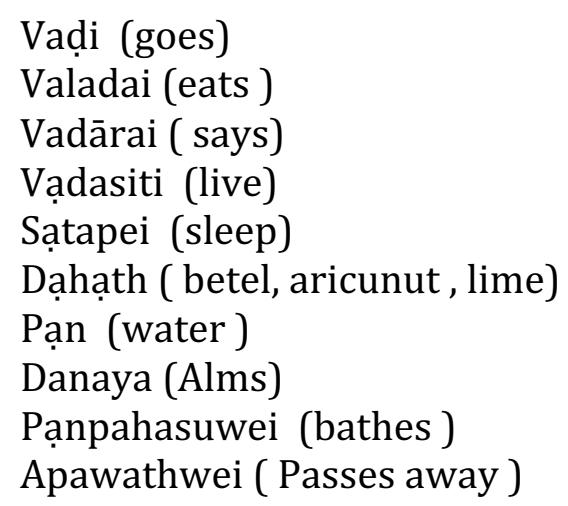

In Sinhala literary tradition ,as a classical text "Sinhala Pansiya Panas Jātaka potha" (Book of birth stories) achieves a Signification pace. There was no any other book which was very popular among readers. Sinhala Jātaka Potha caused to make good formalities in Sinhala society. Pople could make a spiritual life according to these stories, even at present. Following words taken from "Jātaka Pota" are used in colloquial Sinhala commonly. These words have been attributed the people with various qualities.

Kevatțayek

Pinguțtara wagei

Kālagola

Mūsilayek

Kālakaṇnịiek

Bakatapas

Porisādayek

Guttila wagei

Pabawati wagei

Senakayek

Bhūtayek

Disāpāmok wagei

Murugasan warṣāwak

Jūjakayek

Wessantarakāle

When we study modern colloquial Sinhala, some Buddhist terms can be found out preceded with modern technical terms, Such as,

- Offering of Songs

- a campaign of Sila

- a campaign of alms

The accuracy of using those terms ahould be discussed. How ever according to above facts, we can identify clearly the Buddhist influence for the expansion of Sinhalese word stock.

\title{
End Notes
}

\author{
${ }_{1}$ Mahāwamsa ; (Ed) Wilhelm Geiger ; vii chapter \\ 2Mahāwamsa ; (Ed) Wilhelm Geiger ; vii chapter \\ ${ }^{3}$ Mahāwamsa ; (Ed) Wilhelm Geiger ; chapter VIII \\ ${ }^{4}$ Mahāwamsa ; (Ed) Wilhelm Geiger ; chapter IX \\ 5Walpoala , Rahula, History of Buddhism in Sri Lanka \\ 6Mahāwamsa ; (Ed) Wilhelm Geiger ; chapter IX \\ 7Mahāwamsa ; (Ed) Wilhelm Geiger ; chapter X
}


${ }^{8}$ Mahāwamsa ; (Ed) Wilhelm Geiger ; chapter VIII

${ }_{9}^{9}$ Senarath Paranavitana - Inscriptions of Ceylon Vol.1 Ins No. 01

10IC, I, No, 02Ez.V.pp. $210 \mathrm{f}$

11 IC, I, No, 03

${ }_{12} \mathrm{IC}, \mathrm{I}, \mathrm{No}, 04$

${ }_{13}$ IC, I, No, 05

${ }_{14}$ Senarath Paranavitana - Inscriptions of Ceylon Vol.1 Ins No. 02

${ }_{15} \mathrm{IC}, \mathrm{I}, \mathrm{No}, 46 \mathrm{Ez} . V . p p .210 \mathrm{f}$

${ }_{16} \mathrm{IC}, \mathrm{I}, \mathrm{No}, 80 \mathrm{Ez} . V . p p$. If

17 IC, I, No, 64Ez.V.pp. $223 \mathrm{f}$

${ }_{18}$ Sidat Saǹgarā (Ed) Munidāsa Kunaratunga

${ }_{19}$ A.W. Adikaram. Early History of Buddhism in Ceylon, Pages 41" 42

${ }_{20}$ A.M. Gunasekara A comprehensive Grammar of Sinhalese Language, Pages 400" 4

\section{Original Sources}

\section{BIBLIOGRAPHY}

- Dampiyā Atuwā Gạtapadaya. D.B. Jayathilaka(Ed).Colombo.M.D. Gunasena 1932

- Sidath Saǹgarāva. Munidasa Kumarathunga(Ed).Maradana. S. Godage3 1963

- The Jātakās . E.B. Cowell(Ed) London. 1957.

- Samantapāsādikāwa . Takakasu and M. Nagai (Ed) Colombo. M.D. Gunasena 1947

\section{General Books}

- Adikaram A.W. Early History of Buddhism in Ceylon, $2^{\text {nd }}$ impression. Colombo. M.D. Gunasena 1946.

- Darmadasa K.N.O. Language and society. Colombo. M.D. Gunasena 1972

- Gunasekara A.M. A comprehensive Grammar of Sinhalese Language. New Dilhi.Asian educational Services 1986

- Karunathilaka W.S. Sinhalese Grammar. Colombo M.D. Gunasena 1995.

- Perera H.R.Buddhism in Sri Lanka. A short History. Kandy.1988

- Rahula, Walpola History of Buddhism in Sri Lanka. Dehiwala. Buddhist cultural center 1993

- Thennakoon Wimalananda The ancient Ceylon and Inscriptions. Colombo. M.D. Gunasena 1986. 